\title{
The Determinants Factors of Accounting Students' Interest in Sharia Career
}

\author{
Ade Elsa Betavia ${ }^{1, *}$, Dian Fitria Handayani², Vanica Serly ${ }^{3}$ \\ ${ }^{1,2,3}$ Universitas Negeri Padang, Padang, Indonesia \\ "Corresponding author. Email: elsabetavia@gmail.com
}

\begin{abstract}
This study aims to examine the influence of personality, self-efficacy and spiritual motivation on accounting students' Interest in Sharia career. The respondents were 133 accounting students of Universitas Negeri Padang. The sample was determined by purposive sampling method. The data was gathered by survey technique with questionnaires distributing to the respondents. The data was analyzed by using multiple regressions. The study resulted that personality has no effect on accounting students' interest in Sharia career, while self-efficacy and spiritual motivation have a positive effect on career interest in Sharia Entities
\end{abstract}

Keywords: Personality, self-efficacy, spiritual motivation, sharia career interest.

\section{INTRODUCTION}

Higher education has subtantial role in improving the quality of human resources as a place to form professional through teaching and learning activities. A good university will produce professional candidates with quality that will be absorbed into the work field. This quality is achieved by equipping the students with the course that are in accordance with their profession and adapt to the demands of the labor market share.

Sharia Business is largely growing in muslim countries, include Indonesia. The large demand for scholars who understand Sharia business has resulted in increasing job vacancies. Many vacancies in Islamic entities must be balanced with scholars who are competent in the field of Sharia. In line with the rapid development of the Sharia business world, Universitas Negeri Padang (UNP) offers Islamic financial accounting courses as career support for students.

Sharia accounting or Islamic accounting defines as the accounting process for transactions in accordance with the rules set by Allah SWT. Thus, studying Islamic accounting means understanding of Islamic rules implicated in Islamic accounting. There are two main reasons why Islamic accounting is needed, namely the demands for the implementation of Sharia and the need for the rapid development of Islamic transactions ${ }^{11}$. In addition, Islamic accounting is needed to support business with Sharia spirit. This not possible to apply Sharia accounting if the transactions carried by the accounting process are not in accordance with Sharia itself ${ }^{12]}$.

Previous research show the results' gap about the factors determining students' career interest on
Sharia studies.the spritual motivation and social values have have a significant effect on students' carrer interest ${ }^{3]}$. Meanwhile, extrinsic motivation and personality did not have a significant effect on student interest in working in Islamic banking. In contrast, another research show personality has a significant influence on student career interests ${ }^{14]}$. In this research, the authors limit the factors studied, namely personality, self-efficacy and spiritual motivation which are focused on the interest of accounting students for careers in Islamic entities.

Theory of planned behavior adding a construct to understand this research. This theory focused on human behavioral ${ }^{15]}$. It is defined as a theory to predict various behaviors, one of which is to predict consumer behavior. In this research, this theory predicts students' interest in choosing their professionn. Students are similar to consumers who will choose a company to develop their career in ${ }^{16]}$.

Interest comes from person's inner interest toward something ${ }^{7]}$. As consequence, it will encourage person to make a decision/action based on their inner calling. Basically, interest and motivation are two inseparable things. Motivation and interest are the reasons for every action, including in career selection. Career is seen as a series of promotions to get a job that has a higher responsibility load or a better position in a person's job hierarchy ${ }^{18]}$. Having a career which comes from good interest will impact to individual career position.

Personality can affect a person's behavior, performance, and relationship in the work field. Personality determines the length of a person's career in the company. A job that is in accordance with the personality will make employees feels 
comfortable to do the job and extend the career life. Jobs that are not as expected with personality will make employees feel uncomfortable and have the potential to shorten their career life. Some studies found that personality affects the interest in choosing a career to be an accountant ${ }^{19]}$. Another research states that intrinsic motivation show a positive relationship with career path ${ }^{10]}$.

Confidence can be interpreted as self efficacy. Self-efficacy is an individual's belief that he/she will be able to do something in a certain situation successfully ${ }^{111}$. With the existence of self-efficacy, individuals have motivation to overcome obstacles, thus they can make decisions to achieve the desired results. In the process of making decision about career, the individual must know his incompetence on the field of interest, the certainty and future career and what he is really looking for about the career ${ }^{12]}$. Therefore, to overcome the inability to assess their own abilities, individuals must have self-efficacy.

Spritual motivation is related to the interest of Islamic fiannce students to work in Islamic banking $^{33}$. This resercah explains that students are interested in Islamic banking career to show their worship to Allah. Then, they argue that choosing in Islamic career as a form of self-actualization as a servant of Allah. The spritual motivation support them to choose carrer that accordance with Islamic principles. They confess that, Islamic banking are in accordance with Islamic provisions.

Personality, self efficacy and spritual motivation are the factors determing students' interest in choosing Islamic career. Personality related to how students expected their career in accordance with their personal feelings. Self efficacy show how individuals to have independence and confidence to make successful career choices based on their interests and abilities. Then, spritual motivation urge students to choose the job as the worship to the God.

From the explanation above, then the hypothesis proposed are:

H1: Personality has a positive effect on the interest of accounting students to have career in Islamic entities

H2: Self-efficacy has a positive effect on the interest of accounting to have career in Islamic entities
H3: Spiritual motivation has a positive effect on the interest of accounting to have career in Islamic entities

\section{METHODS}

This study took population of undergraduate students majoring in Accounting, Economics faculty, Universitas Negeri Padang. The sampling technique in this study was purposive sampling. This type of research is quantitative research. Then, to anlyze the data, this research used multiple linear regression analysis.

The data source was primary data by using questionnaire distributed to respondents. The questionnaire is divided into two parts, the first part contains demographic data of the respondents and the second part contains factors that are considered to influence the respondents' career choices. The first is about personality, the second is about selfefficacy and the third is about spiritual motivation. Respondents were asked to answer questions in the second part based on a 4-point Liker scale, they are: Score $1=$ Strongly Disagree (SD); Score $2=$ Disagree (D); Score $3=$ Agree (A); Score $4=$ Strongly Agree (SA)

\section{RESULTS AND DISCUSSION}

Respondents used in the study were 133 students majoring in accounting at the Faculty of Economics UNP year 2017 and 2018. From 133 respondents, $20 \%$ were male, while $80 \%$ were female. The validity test is used to measure whether a questionnaire is valid or not. A questionnaire is said to be valid if $r$ count $>r$ table. The validity test can be seen in the Corrected Item Total Correlation column, then compared with the $r$ table value. The $r$ table is searched at a significance of 0.05 with a two-sided test and the amount of data $(n)=133$, df $=n-2$, then the $r$ table is 0.1703 . The following table shows the validity test of the variables, namely personality (X1), self-efficacy (X2), spiritual motivation (X3) and interest in choosing a career in a Sharia entity (Y).

Based on table 1 below shows the variable personality (X1), Self Efficacy (X2), Spiritual Motivation (X3) and interest in career choice in Sharia Entities (Y) have valid criteria for all statement items with a value of $r$ count $>r$ table and a positive value., then the statement item or indicator is declared valid. 
Table 1. Validity Test Results

\begin{tabular}{|l|l|l|l|}
\hline \multicolumn{1}{|c|}{ Questions } & $\begin{array}{c}\text { Correccted } \\
\text { Item-Total } \\
\text { Correlation }\end{array}$ & r table & Validity \\
\hline X1.1 & 0,605 & 0,1703 & Valid \\
\hline X1.2 & 0,755 & 0,1703 & Valid \\
\hline X1.3 & 0,715 & 0,1703 & Valid \\
\hline X1.4 & 0,652 & 0,1703 & Valid \\
\hline X2.1 & 0,657 & 0,1703 & Valid \\
\hline X2.2 & 0,659 & 0,1703 & Valid \\
\hline X2.3 & 0,731 & 0,1703 & Valid \\
\hline X2.4 & 0,632 & 0,1703 & Valid \\
\hline X3.1 & 0,873 & 0,1703 & Valid \\
\hline X3.2 & 0,863 & 0,1703 & Valid \\
\hline X3.3 & 0,852 & 0,1703 & Valid \\
\hline X3.4 & 0,786 & 0,1703 & Valid \\
\hline Y.1 & 0,807 & 0,1703 & Valid \\
\hline Y.2 & 0,863 & 0,1703 & Valid \\
\hline Y.3 & 0,692 & 0,1703 & Valid \\
\hline Y.4 & 0,803 & 0,1703 & Valid \\
\hline
\end{tabular}

Source: Data Analyzed (2020)

Then, the data is analyzed through reliability test of the questionnaires. A questionnaire is considered reliable if the respondent's answers are consistent over time. The technique used in measuring the reliability is the Cronbach alpha technique.

A variable is reliable if the Cronbach alpha value is $>0.60$. Based on the results of table 2 , it can be seen that variable has a cronbach alpha >
0.60, thus all variables used in this study are reliably.

The reliability test results obtained in this study are as follows:

Table 2. Reliability Test Results

\begin{tabular}{|l|l|l|}
\hline \multicolumn{1}{|c|}{ Variable } & \multicolumn{1}{|c|}{ Cronbach Alpha } & \multicolumn{1}{|c|}{ Reliability } \\
\hline Personality & 0,602 & Reliably \\
\hline Self Efficacy & 0,607 & Reliably \\
\hline Spritual Motivation & 0,865 & Reliably \\
\hline Students' interest in Sharia Career & 0,795 & Reliably \\
\hline
\end{tabular}

The data, then, is analyzed with the normality test. It aims to know whether the regression model has a normal distribution ${ }^{14]}$. To detect whether the residuals are normally distributed, the Kolmogorov-Smirnov (K-S) non- parametric statistical test can be used. Based on table 3, the Kolmogorov-Smirnov value is 1.056 and asymp. Sig. (2- failed) of 0.215. So the asymp value. Sig. (2- failed) is greater than 0.05 , then the data is declared normally distributed. 
Table 3. Normality Test Results using Kolmogorov-Smirnov (K-S)

One-Sample Kolmogorov-Smirnov Test

\begin{tabular}{|ll|r|}
\hline & & \multicolumn{2}{|c|}{$\begin{array}{c}\text { Unstandardized } \\
\text { Residual }\end{array}$} \\
\hline $\mathrm{N}$ & & 133 \\
Normal Parameters & & .0000000 \\
& Mean & 1.52710580 \\
Most Extreme Differences & Std. Deviation & .092 \\
& Absolute & .041 \\
& Positive & -.092 \\
Kolmogorov-Smirnov Z & Negative & 1.056 \\
Asymp. Sig. (2-tailed) & & .215 \\
\hline
\end{tabular}

a. Test distribution is Normal.

Multicolonierity test was conducted to know a correlation among independent variables (independent). A model is said to be free of multicollinearity if it has a VIF value $<10$ and a tolerance value $>0.10$. Based on table 4 , it can be concluded that there is no multicollinearity in this study because each variable has a VIF value $<10$ and a tolerance value $>0.1$. The following are the results of the multicollinearity test using tolerance values and variance inflation factor (VIF):

Table 4. Multicollinearity Test Results

Coefficients $^{\mathrm{a}}$

\begin{tabular}{|c|c|c|c|c|c|c|c|}
\hline \multirow[b]{2}{*}{ Model } & \multicolumn{2}{|c|}{$\begin{array}{l}\text { Unstandardized } \\
\text { Coefficients }\end{array}$} & \multirow{2}{*}{$\begin{array}{c}\begin{array}{c}\text { Standardized } \\
\text { Coefficients }\end{array} \\
\text { Beta }\end{array}$} & \multirow[b]{2}{*}{$\mathbf{T}$} & \multirow[b]{2}{*}{ Sig. } & \multicolumn{2}{|c|}{ Collinearity Statistics } \\
\hline & B & $\begin{array}{l}\text { Std. } \\
\text { Error }\end{array}$ & & & & Tolerance & VIF \\
\hline (Constant) & -.714 & 1.407 & & -.507 & .613 & & \\
\hline Total X1 & .161 & .110 & .106 & 1.467 & .145 & .696 & 1.437 \\
\hline Total X2 & .229 & .084 & .196 & 2.735 & .007 & .706 & 1.417 \\
\hline Total X3 & .607 & .070 & .578 & 8.704 & .000 & .827 & 1.209 \\
\hline
\end{tabular}

a. Dependent Variable:

The heteroscedasticity test aims to test whether in the regression model there is an inequality of variance from the residuals of one observation to another. To know the presence or absence of heteroscedasticity, the Glejser test can be seen from the probability of its significance to the level of confidence $(5 \%)$. Table 5 shows that the significance value of the personality variable (X1) is 0960, self-efficacy (X2) is 0.344 and spiritual motivation (X3) is 0.186 . Based on the test results, it shows that all significance values are greater than 0.05 , it can be concluded that there is no heteroscedasticity in this study. 
Table 5. Heteroscedasticity Test Results

\begin{tabular}{|c|c|c|c|c|c|}
\hline \multicolumn{6}{|c|}{ Coefficients $^{a}$} \\
\hline \multirow[b]{2}{*}{ Model } & \multicolumn{2}{|c|}{ Unstandardized Coefficients } & \multirow{2}{*}{$\begin{array}{r}\begin{array}{c}\text { Standardized } \\
\text { Coefficients }\end{array} \\
\text { Beta }\end{array}$} & \multirow[b]{2}{*}{$\mathbf{t}$} & \multirow[b]{2}{*}{ Sig. } \\
\hline & B & Std. Error & & & \\
\hline (Constant) & 2.630 & .932 & & 2.822 & .006 \\
\hline Total X1 & .004 & .073 & .005 & .050 & .960 \\
\hline Total X2 & -.053 & .056 & -.098 & -.950 & .344 \\
\hline Total X3 & -.061 & .046 & -.126 & -1.329 & .186 \\
\hline
\end{tabular}

In this study, the hypothesis was tested by performing the $\mathrm{t}$ test, $\mathrm{F}$ test and determinant coefficient test. If the significant value $<0.05$, the independent variable is able to significantly influence the dependent variable or the hypothesis is accepted. The following are the results of the $t$ test using the SPSS 16 statistical test:

Table 6. $\mathrm{t}$ Test Results

Coefficients $^{\mathrm{a}}$

\begin{tabular}{|c|c|c|c|c|c|}
\hline \multirow[b]{2}{*}{ Model } & \multicolumn{2}{|c|}{$\begin{array}{l}\text { Unstandardized } \\
\text { Coefficients }\end{array}$} & \multirow{2}{*}{$\begin{array}{r}\begin{array}{c}\text { Standardized } \\
\text { Coefficients }\end{array} \\
\text { Beta }\end{array}$} & \multirow[b]{2}{*}{$\mathbf{t}$} & \multirow[b]{2}{*}{ Sig. } \\
\hline & B & Std. Error & & & \\
\hline (Constant) & -.714 & 1.407 & & -.507 & .613 \\
\hline Total X1 & .161 & .110 & .106 & 1.467 & .145 \\
\hline Total X2 & .229 & .084 & .196 & 2.735 & .007 \\
\hline Total X3 & .607 & .070 & .578 & 8.704 & .000 \\
\hline
\end{tabular}

a. Dependent Variable: Total Y1

From table 6, it can be explained whether or not there is an influence between the independent variable on the dependent variable, as follows:

1. Personality (X1) has no effect on career interest in Islamic entities (Y), because t count $<t$ table $(1.467<1.977)$, or seen from the significance value of $0.145>0.05$.

2. Self Efficacy (X2) has an effect on career interest in Sharia entities (Y), because t count> $\mathrm{t}$ table $(2,735>1,977)$, or seen from the significance value of $0.007<0.05$.
3. Spiritual motivation (X3) has an effect on career interest in Islamic entities (Y), because $t$ count $>t$ table $(8.704>1,977)$, or seen from the significance value of $0.000<0.05$.

In table 7 , the $F$ value is obtained with a significance level of 0.000 or less than 0.05 , then the regression model can be said that personality, self-efficacy and spiritual motivation together (simultaneously) have an effect on career interest in Islamic entities.

The Following table are the results of the F test:

Table 7. F Test Results

\begin{tabular}{|l|r|r|r|r|r|}
\hline \multicolumn{7}{|c|}{ ANOVA $^{\mathbf{b}}$} & Sig. \\
\hline Model & Sum of Squares & Df & Mean Square & F & Sig \\
Regression & 347.477 & 3 & 115.826 & 48.538 & $.000^{\mathrm{a}}$ \\
Residual & 307.831 & 129 & 2.386 & & \\
Total & 655.308 & 132 & & & \\
\hline
\end{tabular}

The coefficient of determination $\left(\mathrm{R}^{2}\right)$ in essence measures how far the model's ability to explain the variation in the dependent variable. The following shows the results of the coefficient of determination $\left(\mathrm{R}^{2}\right)$ : 
Table 8. Determination Coefficient Test Results $\left(\mathrm{R}^{2}\right)$

\begin{tabular}{|r|r|r|c|r|}
\hline Model & R & R Square & $\begin{array}{c}\text { Adjusted R } \\
\text { Square }\end{array}$ & $\begin{array}{c}\text { Std. Error of the } \\
\text { Estimate }\end{array}$ \\
\hline 1 & .72 & .53 & & .519 \\
& $8 \mathrm{a}$ & 0 & & 1.54476 \\
\hline
\end{tabular}

Based on table 8 , it is known that the adjusted R Square value is 0.519 or $51.9 \%$. This means that $51.9 \%$ of the variables of career interest in working in Sharia entities (Y) could be explained by personality, self-efficacy and spiritual motivation variables. While the rest, namely $(100 \%$ $-51.9 \%=48.1 \%$ ) is explained by other variables out of the model.

\section{DISCUSSION}

Based on the data analyzed, personality do not contribute to accounting students' career interest in Islamic entities. The personality is related to one fit in the profession, namely personality. This result is similar with previous research ${ }^{[15]}$ which stated that personality has no influence on student career interests.

The self-efficacy is found to have effect on accounting students' career interest in Islamic entities. The previous reserach has similar result with this study. Research ${ }^{[16]}$ proving that selfefficacy affects students' interest in entrepreneurship. Furthermore, research ${ }^{[17]}$ found that self-efficacy has an effect on interest in entrepreneurship.

The spiritual is found to have effect on accounting students' career interest in Islamic entities. This is consistent with research ${ }^{[1]}$ which found that spiritual motivation has a significant effect on interest in accounting students. Students who have a good spirituality will tend to get a job that is in accordance with their beliefs.

From the results obtained, the $\mathrm{T}$ count is positive, meaning that the higher the spiritual motivation, the higher the stability in student decision making for careers in Islamic entities and the lower the spiritual motivation, the lower the student's stability in making career decisions in Islamic entities.

\section{CONCLUSION}

Personality does not affect to accounting students' career interest in Islamic entities. Selfefficacy and spritual motivation has influence on accounting students' career interest to get a job in Islamic entities. This research has limitations to test only three variables. The future reserach should be able to further explore for others factors. For further researchers, it is suggested to develop this research by examining other factors that influence career choice in specific Islamic career, such as Islamic public accountant. In addition, it also adds other methods outside the questionnaire to overcome weaknesses that may exist in the questionnaire method.

\section{REFERENCES}

[1] Islamylia, \& Mutia, E. (2016). The Influence of Attitudes, Subjective Norms, Behavior Control, Spiritual Motivation on the Interest of Accounting Students in Choosing a Sharia Accounting Concentration at the Faculty of Economics, Syiah Kuala University. Accounting Student Scientific Journal, 1(1), 192-203

[2] S. Nurhayati dan Wasilah (2009). Sharia Accounting in Indonesia, Jakarta: Salemba Empat

[3] Setyawati, E. T. 2015. Factors Affecting the Interest of Islamic Finance Department Students of UIN Sunan Kalijaga to Work in Syari'ah Banking. Thesis. Yogyakarta: Fakultas Syariah Dan Hukum UIN Sunan Kalijaga.

[4] Suyono, N. A. (2014). Analysis of Factors Affecting Career Selection as Public Accounting (Empirical Study on Accounting Students of UNSIQ). Journal PPKM, (ISSN: 2345-869X), 69-83.

[5] Jogiyanto, H.M. (2007). Behavioral Information System Yogyakarta: Penerbit Andi

[6] Firmansyah, Edo. 2014. Factors Influencing the Decisions of Accounting Professional Education Students in Choosing Careers in Big Four and Non Big Four Public Accounting Firms (Empirical Studies on Accounting Professional Education Students of UNDIP and UNISBANK). Thesis Fakultas Ekonomika dan Bisnis Universitas Diponegoro Semarang. 
[7] Foerthiono, A. N., \& Sadjiarto, R. A. (2014). Factors Influencing the Interest of Accounting Students in Career as Public Accountants with Ethical Perceptions of Accounting Scandals as Intervening Variables. Tax \& Accounting Review, 4(2), 1-7.

[8] Merdekawati, Dian Putri, dan Sulistyawati, Ardiani Ika. 2011. Factors Affecting Career Selection of Public Accountants and NonPublic Accountants. Journal of Accounting, 13(1), 9-19.

[9] Hong Ng, Y. et. al. (2017). Factors influencing accounting students ${ }^{\text {ee }}$ career paths. Journal of Management Development, Vol. 36 Iss $3 \mathrm{pp}$.

[10] Odia J. O., dan Ogiedu K. O. (2013). Factors affecting the study of accounting in Nigerian Universities. Journal of Educational and Social Research, Vol. 3, No.3

[11] Tarsidi, Didi. 2007. Application Theory of Self Efficacy on Career Development and Career Counseling. Universitas Pendidikan Indonesia

[12] Bandura, A. 1997. Self Efficacy in Changing Societies. USA: Cambridge University Press

[13] Bisri, M. (2013). Statistik. Surakarta: IAIN Surakarta

[14] Ghozali, I. (2016). Multivariate analysis applications with IBM SPSS Program 23 (8th ed.). Semarang: Badan Penerbit Universitas Diponegoro.

[15] Asmoro, T. K. W., Wijayanti, A., \& Suhendro. (2015). Determinants of Career Selection as Public Accountants by Accounting Students. Journal of Accounting and Business Dynamics2(2), 123-135

[16] Marini, Chomzana Kinta dan Siti Hamidah. 2014. Effect of Self Efficacy, Family Environment and the School Environment against SMK Students Interests Hospitality Entrepreneurship ". In the Vocational Education Journal, 04(02), 195-207. Yogyakarta: UNY.

[17] Akanbi, Samuel Toyin. 2013. "Familial Factors, Personality Traits and Self Efficacy as Determinants of Entrepreneurial Intention among Vocational Based Colege of Education Students in Oyo State, Nigeria”. DalamJurnal African Symposium, Volume 13 No.02. Hal.66-76. Nigeria: Oyo State. h.11, h.39 